\title{
The Age of Personalized Parties: Survival and Revival of Party Personalization in the Philippines and Indonesia
}

\author{
Arya Budi \\ College of Asia and the Pacific \\ Australian National University \\ Canberra, Australia \\ arya.budi@anu.edu.au
}

\begin{abstract}
Given the fact that both Indonesia and the Philippines are considered to have procedural democracies, this research sets out to seek how dominant features of party organization are exhibited and why such features emerge or prevail in both countries. In doing so, this research assesses the party leadership and intra-party democracy index in twenty political parties in both countries. The party leaderships are identified with examining how the party leaders institutionalize their power and how the leadership selections are institutionally conducted. Meanwhile, findings of intra-party democracy are analysed through employing measurements of intra-party democracy index of the party statutes in each party. This research concludes that parties in both countries suffer from party personalization in certain ways. The low intra-party democracy and the nature of presidency foster the revival and survival of party personalization in Indonesian and Philippines parties, respectively.
\end{abstract}

Keywords - party personalization; intra-party democracy; Indonesia; Philippines

\section{INTRODUCTION}

Party organization is an important dimension-in accordance with social rootedness, party competition, and legitimacy - for party system institutionalization (Mainwaring and Scully 1995), which in turn contributes to democratic consolidation. This paper assesses the party organization in Indonesia and the Philippines. Accordingly, given the fact the political reforms were begun in the post-authoritarian regime, how Indonesian and Philippine parties run their organization? Why do such party organizations survive or even revive in the countries? Proposing an institutional approach, I argue thatparties in both countries suffer from party personalization in certain ways. In addition, the extent to which intra-party democracyin accordance with modes of the presidencyexplainssuch party personalization in the Philippines and Indonesia. This paper is thus devoted to assessing furtherfeatures of party personalization in the Philippinesand Indonesiaaround the last elections.

Party personalization means that the paramount leaders are no longer merely veto players (Budi, 2014) but that they fully control the working of party organization by holding executive positions of the organizational structure and are actively involved in day-to-day party politics with excessive power. This party personalization $\mathrm{I}$ argue is in turn regarded as a personalistic party derived from electoralist party (Gunther and Diamond, 2003), though some observers suggest hybrid features of such a party in Southeast Asian countries including Indonesia and the Philippines (Tomsa and Ufen, 2013)

The rationale of comparing Indonesia and the Philippines is that both countries employ presidential system a relatively similar regime type. Both the Philippines and Indonesia are credited as 'Democracy' regimes with score of 8 in Polity IV (2014). Furthermore, democratic experiences in both Philippine and Indonesia have been gradedat a similar level. Almost two decades after the fallen of Ferdinand Marcos authoritarianism, the Philippines still suffers a stagnancy in its democratic consolidation which Freedom House (2015) credited only Partly Free with 10/16 for its Political Pluralism and Participation. Meanwhile, after the fall of Suharto regime Indonesian democracy fluctuates but currently tends to decline which can be seen by Freedom House (2015) downgrading its democracy into Partly Free-from Free in 2006-2012despite a higher score 14/16 of Political Pluralism and Participation.

This paper, referring to one of the Katz and Mair's (1994) three faces of political party, tries to present an analysis of the 'party in central office' to complement the existing analyses regarding 'party in public office' (oligarchy and cartelization) and 'party on the ground' (patron-client and social cleavage) in Indonesian and Philippine studies, respectively. In the Philippines in which families are the strongest institution (McCoy 1996), some argue that patronclient relations (Landé 1967, Sidel 1999)and the absence of politicization of social cleavages (Ufen 2008, Quimpo 2007, Manacsa and Tan 2005) explain such causal inferences about party personalization. In the Indonesian case, the resilience of oligarchs(Robison and Hadiz 2004, Hadiz 2014, Winters 2011) and the rising of cartel parties (Slater 2004, 
Ambardi2009) are presumed in explaining personalization of political parties.

Stemming from institutional claims, this paper will be presented into three main parts. In the first part, this paper will argueIndonesia's parties tend to be personalized which coincides with the nature of the Philippines' personalistic parties seen in the second part.Then, at last, I will assess intraparty democracy regarding the party institutionalization and the modes ofpresidency - authorities and the privileges - in the two countries that explain2such survival and revival of party personalization.

\section{INCLINATION OF PERSONALIZED PARTIES IN INDONESIA}

In Indonesia, some believe thatpolitical parties remain in being hijacked by oligarchs and are trapped in cartelized inter-party politics since democratization after the fall of Suharto. Thus party competition and intra-party politics are devoted to the oligarchs who obviously co-opt the party through their economic capital in order to maintain and generate more economic spoils. I agree with the roles of oligarch and the economic motives, this paper nevertheless argues that economic capital is not a single determinant explaining such oligarch survival in Indonesian democratic circumstances. Oligarchs do not simply maintain his/her power by distributing resources.

This paper, however, contends that such oligarchs transform into paramount party leaders who explicitly and totally control the party into party personalization. Extensive party personalization of post-2014 election results in such cooptation of intra-party politics which in turn is to be cooperation of inter-party politics. Personalization tendency is different with presidentialization theses (Ufen 2008, Mietzner2009) which produce 'presidentialist party'. Presidentialization stems from the notion of the origin of the party which has been the basis of chasing presidential ticket signified by the emergence of Democrat in 2003, Hanura in 2007 and Gerindra in 2008.

Such party personalization is conducted into two mechanisms in current Indonesian parties. First, the leader holds both legislative and executive power concurrently. This feature of personalization is committed by Susilo Bambang Yudhoyono in Democrat congress April 2015, Surya Paloh in Nasdem congress January 2013 and Prabowo Subianto in Gerindra congress September 2014 by shifting themselves into absolute one-man show. These party patron hold advisory councils (Majelis Tinggil Dewan Pembina) and party chairman concurrently. Second, the leader holds only executive power but with very excessive power formally and informally. PKB, for instance, after longstanding conflict between Muhaimin and Gus Dur in 2008 which was ended up by Muhaimin leadership, eventually reduces significantly the authority of party's advisory council (Dewan Syura)in the Muktamar (congress) August 2014.Only do two parties, namely, PAN and PKS in which the inclination of personalization does not happen though PAN violates its statute in order to provide new position for the patron Amien Rais by creating Dewan Kehormatan (Honorary Council) in party congress in March 2014 which never exist previously in PAN's organizational history.

To be sure, such party personalizations were orchestrated in the 'constitutionally' acclamation party congresses in order to keep political legitimacy internally for intra-party politics and externally for inter-party politics and public. Those modes of personalization path areundergone with and without significantly violating party statutes. But in general, most political parties except PAN and PKS strategically propose a politics of acclamation which in some parties such as PPP and Golkar result in leadership split. Leadership split in both parties, furthermore, are institutionalized and formalized with the same path: politics acclamation. Paths of party personalization in Hanura and Demokrat, for instance, are conducted neatly and smoothly.

Meanwhile, Golkar and PPP suffers from rough, hard paths of party personalization begun by political delegitimation of the incumbency which in turn, except Golkar's Agung Laksono camp, legitimize each leadership camps by doing politics of acclamation either Golkar's Aburizal Bakrie, PPP's Romahurmuzy, or PPP's Djan Faridz. Regardless of the intraparty politics contesting the party leaders and their followers, such dramatic, unresolved paths of personalization in both parties are obviously influenced by the governing coalition of Jokowi's cabinet having state authority determining the legal standing of a party leadership.

\section{The NATURE OF PARTY PeRsonalization IN THE PHILIPPINES}

First of all, in a nutshell the Philippines' political parties are very fragile. They can be 'something' from 'nothing' and vice versa. Political parties merely constitute political machinery for individuals or families rooted in Philippine social structure (McCoy 1996). Thus, comparing tothe elite-based approaches of Indonesian party politics, Philippine political parties are mostly seen in its linkage with the society. In this regard, there are two dominant points of view explaining the dependency of partyinstitutions upon individual patronages in the Philippines: patron-client relationship (Landé 1973, Sidel 1999)and the absence of social cleavagepoliticization (Ufen 2008, Quimpo 2007, Manacsa and Tan 2005). The notion of patron-client thesesrelates to the working of two things. One is genetic networks which are expressed into the studies about politics of clan, kinship, and family (Lande 1968, Case 1999) hijacking political party. The other is clientelistic motives related to pyramidal patronage networks distributing spoils of office from the national level into the local level. The forming and the working of political parties following this thesis are mainly based on individual capital which is mostly regarded as material resources (Winters 2011, Sidel 1999). In terms of the absence of social politicization, in short, neither Lipset and Rokkan's social cleavage nor Lijphar's (1973) consociational ideal meet to the Philippines' parties since parties simply constitute a political armour for an electoral battle.

While the patron-client causationis close to the oligarchy theses in Indonesian, the absence of social cleavage in Philippine parties is an apparent worldwide party tendency 
as social cleavage had been abandoned in western democracy in which Kirchheimer's catch-all party thesis coincided with German's SPD, Spanish's PSOE, and French's Socialist party coming to get closer each other ideologically and programmatically to the center along post-war period (Blondel and Thiébauld, 2010: 19).It is obvious nevertheless that Lipset and Rokkan's social cleavages are better and clearer represented in Indonesian parties than those of the Philippines. Another thing, thus, we should consider is the working of the parties in their 'face of central office' (Katz and Mair 1996). In this regard, Philippine parties can be viewed as the nature of personalistic partiesrelying on individual influence.

I argue there are three main features of party personalization in the Philippines. First, politicians easily split, incorporate or switch their party affiliation and even 'temporary' establish a party_-which this feature may produce difficulty for observers to identify the 'party activists' - in accordance with presidency. For instance, some argue that Philippine political parties in the last three decades after the fallen of Ferdinand Marcos can be classified into four most survived parties, namely, Liberal Party and Laban ng Demokratikong Pilipino (LDP) prior to 1990 and Lakas Kampi-CMD (LKC) and Nationalist's People Coalition (NPC). All those parties survive because of the winning presidential candidate such as Corazon Aquino'sLDP, Fidel Ramos's Lakas KAMPI-CMD and Joseph Estrada's NPC (see Teehankee 2012). In contrast, different with Indonesia's Golkar surviving in post-authoritarian patronage, Marcos' New Movement Society (KLB) - currently led by Imelda Marcos-has perished in national party competition into provincial level party in Ilocos Norte. Since politicians follow where the 'wind blows' in Philippine politics, promising or elected presidential candidate's (coalition) party gain the highest number of seats in the three-year term congressional election. As a result, the longevity of a political party firmly depends on the political survival of the political patronage.

Second, in the last decade party leadership survived in some parties such as Nacionalist Party's Manual Villar, LPD's Egardo Angara or PMP's Joseph Estrada but some major parties suffered leadership vulnerability such as Liberal Party and Lakas-CMD which have rapid leadership change with about less than a year. Lakas-CMD, for example, has different party chairmen/women-Gloria Machapagal Arroyo, Gilberto Teodoro, Amelita Villarosa, Edcel Lagman, and Bong Revilla, Jr-in only five years from 2008-2013. In addition, it is hard to mention the real party chairman controlling party activism as there are several-usually three-top executive positions acting as the leader such as president, titular chairman, chairman and the party's elected presidential candidate. Only does Akbayan have different pattern. Though the party is a marginalized party based on its participation in party-list election gaining 2 seats of 2013 House of Representative election, its leadership is significantly fulfilled by young party activists (23-36 years old) which had been elected in the $6^{\text {th }}$ party congress last April 2015.
Third, regarding the 'party in central office', weak party institutions are also signified by the fluid membership. For example, there are 14 elected congressmen running under two or more political parties in 1992 congressional election. Gloriya Macapagal Arroyo's multi-membership of political parties is the most tangible evidence in this instance. She was a founding member of KAMPI, but was a candidate for LakasNUCD, and then at the same time was an honorary chairwoman of the Liberal Party (see Ufen, 2007: 15). Though Liberal party - in accordance with Akbayan party-constitutes the most programmatic party compared to the other parties (Bevis, 2006), party switching is rampant which simply follows the winning presidential candidate in the last election. In average, there are bout $40 \%$ of incumbent members and $25 \%$ of incumbent senators switch their party affiliation from one to another election (Kasuya 2009). In a particular case, Liberal Party gaining 108 seats in 2013 election had much lower seats in 2010 (45 seats) and 2007 (23 seats) since Benigno Aquino III nominated by Liberal Party won in 2010 presidential election.

\section{INSTITUTIONALIZED PERSONALIZATION: THE PARTY AND THE PRESIDENCY}

Though both Indonesian and Philippine parties indeed can be classified as electoralist parties (Tomsa 2013, 20-38), Philippine nature of individual centred parties and inclination of Indonesian parties personalization signify the coming of the age of personalistic parties in the region. This paper argues that the extent to which the intra-party democracy (IPD) is operated by the party in accordance with the party institutionalization and the degree of how the presidency gains political privileges situate such inclination of personalized parties in Indonesia and the resilience of personalistic parties in the Philippines.

First of all, in regard with intra-party democracy analysis, this paper argues that the more democratic an intraparty organization is the less personalized the party. In doing so, assessing party statutes published publicly in their official webpages has significant insight since Indonesian Golkar's and PPP' leadership split following the 2014 presidential election, for example, are contested and canalized into the debate and interpretation of each party statutes. Different with all Indonesian parliamentary parties having party official websites, however, very few Philippine parties activate their organization in the cyber pages given there are $40 \%$ Pilipino compared with $17 \%$ Indonesian internet users of the total population (http://www.internet livestats.com, 30 September 2015). In a glance, reviewing this kind of public access to the party, party institutionalization in the Philippines is worse than that of Indonesian. Philippine national parties of the 2013 election such as UNALDP, and even Lakas KAMPI-CMDthe biggest party during Arroyo administration-donot have official website. Only do Liberal party, NPC, Nacionalista Party and the marginalized party Akbayan party display their organizations into cyber page including their party statutes and platforms (with exception to Nacionalista Party). Thus, 
analysis of intra-party democracy through party statutes is restricted to only the three parties-Liberal, NPC and Akbayan.

By adjusting Berge, Poguntke, Obert and Tipei's (2013) IPD measurement, the seven variables determining intra-party democracy are drawn from three main dimensions, namely, member rights, organizational structures, and decision-making, by weighting the recruitment variable as the most determinant dimension of party institutionalization (Katz 2001; Hazan and Rahat 2010). Weighting the recruitment variable (especially candidate selection) with ' 7 ' encompassing the seven other variables-is crucial sincesuch a variable determines the party organization. United States, for example, in which the Philippines resemble their political system to the colonial has an explicit and extensive regulations ruling the candidate selection conducted by several types of primary - open, closed, and blanket - depended on each state legislation (Gauja, 2010: 99-125). Meanwhile in Australia, Canada and UK candidate selection is a private issue of political parties in which there is no rule regulating how a party selects its candidates; and limited regulations of candidate selection, however, are enacted in New Zealand, Germany, Greece, Norway and Finland.

As shown in the Graph.1, parties with the low degree of intra-party democracy sufferfrom party personalization as explained in the previous sections about the Indonesian and Philippine case. For instance, Indonesian PDIP has the lowest score (3.0) of Intra-Party Democracy in which the party maintain the statute drafted loosely without specific rules or procedures in several key points such as the candidacy or the responsibility of the executive organ especially the chairmanship. In contrast, a new-left Akbayan with more than 8 of theIPD score in the Philippines tries to institutionalize the organization by stimulating clearly many dimensions assessed as intra-party democracy such as the declaration as a massbased party which is derived from specific points how such a principle works.

Graph 1.

Intra-party Democracy of the Philippine and Indonesian Parties

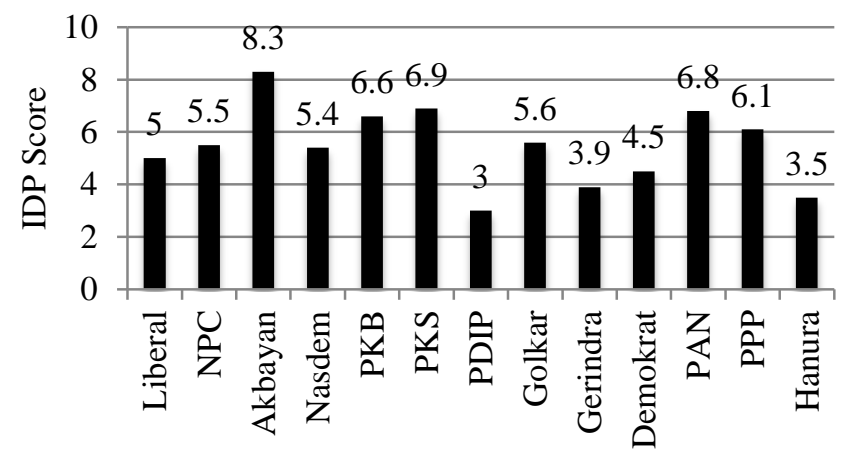

Philippine and Indonesian Parties

Secondly, presidency matters in shaping the party personalization in both countries in which arguably the presidential system itself. A governmental system, situates the emergence of one-man show politics (Linz 1990). The most tangible empirical argument the paper propose is that the power of controlling state resource. Though Philippine presidential post has less paid than Indonesian president with US32,513 and US\$124,171 (http://www.internetlivestats.com/, accessed in 30 September 2015), the Philippine president enjoy a discretionary spending called, for example, Nonoy's Disbursement Allocation Program and President's Social Fund (The Wall Street Journal, 3 October 2013), which is potentially utilized to maintain patronage networks into local levels. Indonesian president, in contrast, has no such pork barrel but still has authority for determining state-owned enterprises' executive and ministerial and cabinet posts. Social policies could be deployed for electoral gains like what SBY did by releasing fresh money of oil price adjustment BLT prior to his second presidential candidacy in 2009.

Such presidential privileges over state resources coincided with poor party financing in the Philippines and Indonesia which in turn situates the parties to be more dependent on the (elected or running) presidential candidate. Indonesian and Philippine parties have limited or none public funding. Philippine parties are only regulated for spending and contributors since state subsidies are not provided; and the party financing usually takes place a year before election in which the parties' presidential and parliamentary candidates do not maintain the working of party organization (Tehankee 2012, 197). Meanwhile,state subsidies for Indonesian political parties are even reduced from Rp1000 per votes in 2009 election result into only Rp108per votes of the last election 2014. In this regard, as shown in Graph.1 parties with high IPD score such as Akbayan and PKS even stipulate the membership dues, not only the percentage of salary cut for party functionaries in the public offices like in PKB, PAN, or Golkar. As a result, both Philippine and Indonesian parties corruption index comes after police amid the fact that political parties are the most corrupt institution worldwide in Transparency International's report 2013.

The personalistic parties survive and revive in both countries since the presidency coincided with the poor party financing,the low level of IPD, and the elite competition are intertwined each other. Mainwaring and Torcal(2005: 21) assert that "personalistic linkages between voters and candidates tend to be stronger [...] with weak party organization and weakly institutionalized party". Such survival and revival of party personalization basically can be prevented by regulating the party system. To be sure, party personalization in Indonesia occurs amid party system institutionalization. For instance, party regulation of 2014 election (Law No. 8/ 2012) obligate a party should be nationally established-sufficient number of branches in provincial and district levels, and sufficient membership in each district - to contest in the election. Such party system institutionalization, to be sure, stimulates party incorporation or merger rather than split. It means that leadership split in Golkar and PPP obviously will be endedup approach to the 
2019 election as long as no significant changes of national established party requirements. Philippine regulations related to party institutionalization have minor concerns about the national established party requirements. House Bill 403/ 2010, for example, merely stipulates the party should have a platform. Instead, the House regulates-or explicitly acknowledges - the prevalent party switching among politicians by provisioning about 'changing political party affiliation'.

In addition to the regulation on parties, electoral system indirectly contributes to the party personalization in both countries.Given the fact that two developing democracies employ different electoral system, the Philippines' plurality and Indonesia's Proportional Representative-Philippine' (2013) and Indonesian' (2014) ENPP are about 6.6 and 8.9, respectively (See Tomsa 2013; Gallagher 2015). In addition, the degree of disproportionality - the deviation between seats and votes - in Indonesian parties resulted in 2014 shows the inclination of institutionalization effect-national based party requirement-from $4.45 \%$ in 2004 and $6.85 \%$ in 2009 to only $2.79 \%$ in 2014 (Gallagher 2015). As practical evidence, party splits and mergers are more prevalent in Philippine parties than those in Indonesia. For instance, NPC which is a result of leadership factionalism from Nacionalista's presidential candidacy in 1992 is not similar to Nasdem from Golkar stemming from Golkar's chairman election in the 2009 party congress. The patronages of Hanura and Gerindra stem from Golkar as well but those parties are not a result of leadership factionalism.

\section{CONCLUSION}

This paper, on the one hand, demonstrates that most Philippine parties remain in personalistic nature of intra-party organization and even inter-party competition. On the other hand, Indonesian parties incline to be personalistic. Both the survival and revival of party personalization in the Philippines and Indonesia, respectively, have their own features. However, they are situated in two main causes, namely, the low degree of intra-party democracy and the presidential privileges over resources. Those causes coincide with the poor party financing and the weak party system institutionalization though the latter is obviously endogenous (Randall and Svåsand, 2002: 8). This paper further argues that party system institutionalization by regulating national well-established party, for instance, may prevent party personalization and boost party institutionalization at the same time.

\section{REFERENCES}

[1] Akbayan.. https://akbayan.org.ph/news/32-specials/545-youngprogressives-takethe-helm-of-akbayan-party-leadership, accessed in 25 September 2015.

[2] Ambardi, Kuskridho. Menungkap Politik Kartel: Studi tentang Sistem Kepartaian di Indonesia Era Reformasi. Jakarta: Kepustakaan Populer Gramedia, 2009.

[3] Asian Ranking. "Top 20 Highest Paid Political Leaders in Asia”, in http://www.asianranking.com/top-20-highest-paid-political-leaders-inasia/, accessed in 14 September 2015.
[4] Basedau, Matthias and Alexander Stroh. "Measuring Party Institutionalization in Developing Countries: A New Research Instrument Applied to 28 African Political Parties”. GIGA Working Papers (69). 2008

[5] Berge, Benjamin von dem; Poguntke, Thomas; Obert, Peter; Tipei, Diana. "Measuring Intra-Party Democracy: A Guide for the Content Analysis of Party Statutes with Examples from Hungary, Slovakia and Romania. Heidelberg: Springer, 2013.

[6] Bevis, Gwendolyn G. "Building Programmatic Parties in A PatronageDominated System: Akbayan and the Liberal Party in the Post-1986 Philippines", A Doctoral Dissertation, University of WisconsinMadison. 2006.

[7] Blondel, Jean and Thiébault, Jean-Louis. Political Leadership, Parties and Citizens: The Personalization of Leadership. New York: Routledge. 2010.

[8] Budi, Arya. "Membongkar Veto Player dalam Politik Kepartaian Indonesia Menuju Pemilu 2014”, Jurnal Ilmu Sosial dan Ilmu Politik, Universitas Gadjah Mada. 17(1). 2013: 51-66.

[9] Budi, Arya. Partai Aceh: Transformasi GAM? Yogyakarta: Pol.Gov Press, JPP UGM, 2012.

[10] "BOC Most Corrupt Among 36 Govt-Agencies: SWS Survey", in http://www.abs-cbnnews.com/focus/08/28/15/boc-most-corrupt-among36-govt-agencies-sws-survey, accessed in 10 October 2015.

[11] Concha, Olivares Eduardo. "Institutionalizaiton of Party Systems: A Cross-Regional Approach using the weighted volatility index". Conference Paper of the Political Studies Association 64th Annual International Conference, Manchester: 2014

[12] Constitution and By-Laws: Rules and Regulation of Nationalist People's Coalition (NPC). http://www.npcparty.org/by-laws/, accessed in 1 October 2015.

[13] Croissant, Aurel and Philip Völke. "Party System Types and Party System Institutionalization: Comparing New Democracies in East and Southeast Asia", Party Politics 18(2), 2012: 235-265.

[14] Eklöf, Stefan. Power and Political Culture in Suharto's Indonesia: The Indonesian Democratic Party (PDI) and Decline of the New Order (1986-1998). Copenhagen: NIAS Press, 2003.

[15] Freedom House. https://freedomhouse.org/report/freedom-world/, accessed in 24 September 2015.

[16]

[17] Gallagher, Michael, 2015. Election indices dataset at http://www.tcd.ie/Political_Science/staff/michael_gallagher/ElSystems/i ndex.php, accessed in 10 October 2015.

[18] Gauja, Anika. Political Parties and Elections: Legislating for Representative Democracy. Sydney: Ashgate. 2010.

[19] Gunther, Richard and Diamond, Larry. "Species of Political Parties: A New Typology”. Party Politics 9(2), 2003: 167-199.

[20] Gunther, Richard, Jose Ramon and Juan J. Linz. Political Parties: Old Concepts and New Challenges. Oxford: Oxford University Press. 2002.

[21] Hadiz, Vedi and Robison, Richard. "The Political Economy of Oligarchy and the Reorganization of Power in Indonesia" Indonesia 96. 2013: 35-57.

[22] Hazan, Reuven Y. and Rahat, Gideon, Democracy within Parties: Candidate Selection Methods and Their Political Consequences. Oxford, New York: Oxford University Press. 2010.

[23] http://www.kompas.com

[24] http://www.tempo.co

[25] http://news.detik.com

[26] Imawan, Riswanda, "The Evolution of Political Party Systems in Indonesia: 1900 to 1987". PhD Dissertation. Northern Illinois University, 1989.

[27] Internet Livestats. "Internet Userts by Country", in http://www.internetlivestats.com/internet-users-by-country/, accessed in 30 September 2015.

[28] Kasuya, Yuko. Presidential Bendwagon: Parties and Party System in the Philippines, Tokyo: Keyko University Press. 2009. 
[29] Katz, Richard and Mair, Peter (ed). How Parties Organize: Change and Adaptation in Party Organization in Western Democracies. London: Sage Publication. 1994.

[30] Katz, Richard S. "The Problem of Candidate Selection and Models of Party Democracy". Party Politics 7(3), 2001: 277-296.

[31] Katz, Richard S. and Peter Mair. " Changing Models of Party Organization and Party Democracy: The Emergence of the Cartel Party", Party Politics 1(1), 1995: 5-28.

[32] Lande, Carl H. Leaders, Factions and Parties: the Structure of Philippine Politics. Southeast Asia Studies, Yale University, Monograph Series, 1966.

[33] Mainwaring, Scott and Scully, Timothy R. "Party Systems in Latin America" in Mainwaring, Scott and Scully, Timothy R (ed.). Building Democratic Institutions: Party Systems in Latin America. Stanford: Stanford University Press. 1996: 1-34

[34] Mainwaring, Scott and Torcal, Mariano. "Party System Institutionalization and Party System Theory after the Third Wave of Democratization". Working Paper (319). Kellog Institute. 2005.

[35] Manacsa, Rodelio Cruz and Tan, Alexander C. "Manufacturing Parties: Re-examining the Transient Nature of Philippine Political Parties". Party Politics 11(6), 2005. 748-765

[36] Marshall, Monty G. "Polity IV Individual Country Regime Trends, 1946-2013”, in http://www.systemicpeace.org/polity/polity4.htm, accessed in 16 September 2015

[37] Mietzner, Marcus, Money, Power and Ideology: Political Parties in PostAuthoritarian Indonesia, Singapore: NUS Press, 2013

[38] "Political Parties Are the Most Corrupt Institution According to TI", http://www.transparency.org/news/pressrelease/political_parties_are_mo st_corrupt_institution_worldwide_according_to_ti_gl, accessed in 5 October 2015

[39] "Political Parties Are the Most Corrupt Institution According to TI", in http://www.transparency.org/news/pressrelease/political_parties_are_mo st_corrupt_institution_worldwide_according_to_ti_gl, accessed in 5 October 2015

[40] "Political Parties Seen As Most Corrupt Institutions Globally." In http://www.ipsnews.net/2013/07/political-parties-seen-as-most-corruptinstitutions-globally/, accessed 7 October 2015.

[41] Quimpo, Nathan Gilbert. "The Philippines: Political Parties and Corruption”, Southeast Asian Affairs, 2007: 277-294.

[42] Randall, Vicky and Svåsand, Lars. "Party Institutionalization in New Democracies". Party Politics 8(1). 2002: 5-29.

[43] Sidel, John. Capital, Coercion, and Crime: Bossism in the Philippines, California: Stanford University Press, 2000.

[44] Slater, Dan. "Indonesian Accountability Trap: Party Cartels and Presidential Power after Democratic Transition”. Indonesia 78, 2004: 61-92.

[45] Slater, Dan. "The ironies of instability in Indonesia." Social Analysis 50.1. (2006): 208-213

[46] "Supreme Court Rules Party List not Only for Marginalized", in http://newsinfo.inquirer.net/385839/supreme-court-rules-party-list-notonly-for-marginalized
[47] Tomsa, Dirk and Ufen, Andreas (ed.). Party Politics in Southeast Asia: Clientelism and Electoral Competitionin Indonesia, Thailand and the Philippines. New York: Routledge. 2012.

[48] Tomsa, Dirk. "What Type of Party? Southeast Asian Parties Between Clientelism and Electoralism" in Party Politics in Southeast Asia: Clientelism and Electoral Competitionin Indonesia, Thailand and the Philippines, edited by Dirk Tomsa, and Andreas Ufen, New York: Routledge. 2012: 20-38

[49] Tomsa, Dirk, Party Politics and Democratization in Indonesia: Golkar in the post-Suharto era. London and New York: Routledge, 2008.

[50] Teehanke, Julio. "Electoral Politics in the Philippines" in Electora Politics in Southeast and East Asia. Singapore: Friederich Ebert Stiftung. 2002: 149-202.

[51] Teehanke, Julio. "The Philippines" in Political Parties and Democracy: Contemporary Western Europe and Asia. New York: Palgrave Macmillan. 2012: 187-208.

[52] The Wall Street Journal, "Philippine President Defends His Spending, Blast 'Thieves",, http://blogs.wsj.com/indonesiarealtime/2013/10/31/ philippine-president-defends-his-spending-blasts-thieves/, accessed in 7 October 2015

[53] Ufen, Andreas. "From" aliran" to dealignment: political parties in postSuharto Indonesia." South East Asia Research 16.1. 2008: 5-41.

[54] Winters, Jeffre. Oligarki (translated from Oligachy). Jakarta: Gramedia Pustaka Utama. 2011

[55] Akbayan. "Amended Constitution of the Akbayan". 2010.

[56] Liberal Party. "Amended Constitution of the Liberal Party of the Philippines". 2004.

[57] Nationalist People's Coalition." Contitution and By-Laws: Rules and Regulation." 2002.

[58] Partai Amanat Nasional. "Anggaran Dasar dan Anggaran Rumah Tangga (AD/ART) Partai Amanat Nasional (PAN)".

[59] Partai Nasional Demokrat. "Anggaran Dasar dan Anggaran Rumah Tangga (AD/ART) Partai Nasional Demokrat (NASDEM).

[60] Partai Kebangkitan Bangsa. "Anggaran Dasar dan Anggaran Rumah Tangga (AD/ART) Partai Kebangkitan Bangsa (PKB)".

[61] Partai Keadilan Sejahtera. "Anggaran Dasar dan Anggaran Rumah Tangga (AD/ART) Partai Keadilan Sejahtera (PKS).”

[62] Partai Demokrasi Indonesia-Perjuangan. "Anggaran Dasar dan Anggaran Rumah Tangga (AD/ART) Partai Demokrasi IndonesiaPerjuangan (PDI-P)"

[63] Partai Demokrat. "Anggaran Dasar dan Anggaran Rumah Tangga (AD/ART) Partai Demokrat"

[64] Partai Gerakan Indonesia Raya. "Anggaran Dasar dan Anggaran Rumah Tangga (AD/ART) Partai Gerakan Indonesia Raya (Gerindra)"

[65] Partai Golongan Karya. "Anggaran Dasar dan Anggaran Rumah Tangga (AD/ART) Partai Golongan Karya (Golkar)".

[66] Partai Hati Nurani Rakyat. "Anggaran Dasar dan Anggaran Rumah Tangga (AD/ART) Partai Hati Nurani Rakyat (Hanura)”.

Partai Persatuan Pembanungan. "Anggaran Dasar dan Anggaran Rumah Tangga 